Review

\title{
Development, Performance, and Vehicle Applications of High Energy Density Electrochemical Capacitors
}

\author{
Andrew F. Burke ${ }^{1, *}$ and Jingyuan Zhao ${ }^{1,2}$ \\ 1 Institute of Transportation Studies, University of California, Davis, CA 95616, USA; jyzhao_scholar@yeah.net \\ 2 BYD Automotive Engineering Research Institute, Pingshan, Shenzhen 518118, China \\ * Correspondence: afburke@ucdavis.edu
}

check for updates

Citation: Burke, A.F.; Zhao, J. Development, Performance, and Vehicle Applications of High Energy Density Electrochemical Capacitors. Appl. Sci. 2022, 12, 1726. https:// doi.org/10.3390/app12031726

Academic Editors: Gaind P. Pandey and Young-Kyu Han

Received: 9 November 2021

Accepted: 28 January 2022

Published: 8 February 2022

Publisher's Note: MDPI stays neutral with regard to jurisdictional claims in published maps and institutional affiliations.

Copyright: (C) 2022 by the authors. Licensee MDPI, Basel, Switzerland. This article is an open access article distributed under the terms and conditions of the Creative Commons Attribution (CC BY) license (https:/ / creativecommons.org/licenses/by/ $4.0 /)$.

\begin{abstract}
This paper is concerned with the development and performance of high-energy density electrochemical supercapacitors (ECCs) and their application in HEVs, PHEVs, and HFCVs. Detailed test data are shown for the Skeleton Technology $5000 \mathrm{~F}$ carbon/carbon EDLC device and the Aowei $9000 \mathrm{~F}$ hybrid (4 V) supercapacitor (HSC). The EDLC device had an energy density of $8.4 \mathrm{Wh} / \mathrm{kg}$ and the hybrid SC had an energy density between 30 and 65, depending on its rated voltage and the power of the discharge. These energy densities are significantly higher than previous ECCs tested. They indicate that good progress is being made in increasing the energy density of commercial ECCs. Vehicle applications of the advanced ECCs were evaluated based on Advisor simulations on city and highway driving cycles. Simulations were made for six vehicle types ranging from compact passenger cars to Class 8 long haul trucks. The fuel economy was calculated for each vehicle type using a lithium battery, the EDLC Skeleton Technology capacitor and the two Aowei hybrid capacitors as energy storage in the powertrain. The $4.1 \mathrm{~V}$ hybrid capacitor in all cases was lighter and smaller than the lithium battery. The fuel economies of the HEVs on the FUDS cycle were significantly higher (30-50\%) than that of the corresponding ICE vehicle, except for the long haul truck, for which the fuel economy improvement was $20 \%$. In almost all cases, the fuel economy improvement was highest when using the $4.1 \mathrm{~V}$ hybrid capacitor. Simulations were also run for fuel cell-powered vehicles. For the fuel cell vehicles, the fuel economies using the three energy storage technologies varied only slightly. For all the fuel cell vehicles simulated, the $4.1 \mathrm{~V}$ hybrid capacitor was the lightest and smallest of the energy storage options, and produced the best fuel economy. As in the case of HEVs, the hybrid capacitors appeared to be the best option for energy storage in fuel cell vehicle applications.
\end{abstract}

Keywords: high energy density; electrochemical capacitors; vehicle applications; simulations

\section{Introduction}

This paper is concerned with the development, performance, and application of high-energy density capacitors as energy storage devices in competition with batteries. It is a follow-on paper to one recently published by the authors in the Journal of Energy Storage [1]. As energy storage devices, capacitors have an inherent advantage over batteries in terms of cycle life and power capability, but in most cases they have much lower energy density and higher costs. The relative importance of the advantages and disadvantages depends on the application and the design and performance characteristics of the capacitors and batteries being compared. The capacitors of interest in this paper are electrochemical capacitors. The batteries of primary interest are nickel metal hydride (NMH) and lithiumion (NMC and LTO). In this paper, the electrochemical capacitors (ECC) will be discussed in terms of their energy storage mechanism, electrode materials, and construction. Next, the present commercial status and projected future development of ECCs will be considered. In that section, recent test data taken at UC Davis on advanced ECCs will be presented. The last sections of the paper will include the consideration of ECCs and lithium batteries in several hybrid vehicle applications. In some cases, comparisons are made with using ECCs in place of batteries. These comparisons are made based on computer simulations. 


\section{Energy Storage, Materials, and Construction of Electrochemical Capacitors}

Electrochemical capacitors (ECC) are devices that store electrical energy [2] by capacitive (charge separation) mechanisms and require electrochemical phenomena to function. As shown in Figure 1, the charge is stored in the nanopores of a microporous material that form the electrodes of the device. The construction of the electrochemical capacitor is similar to that of a battery, but they use different materials in the electrodes.

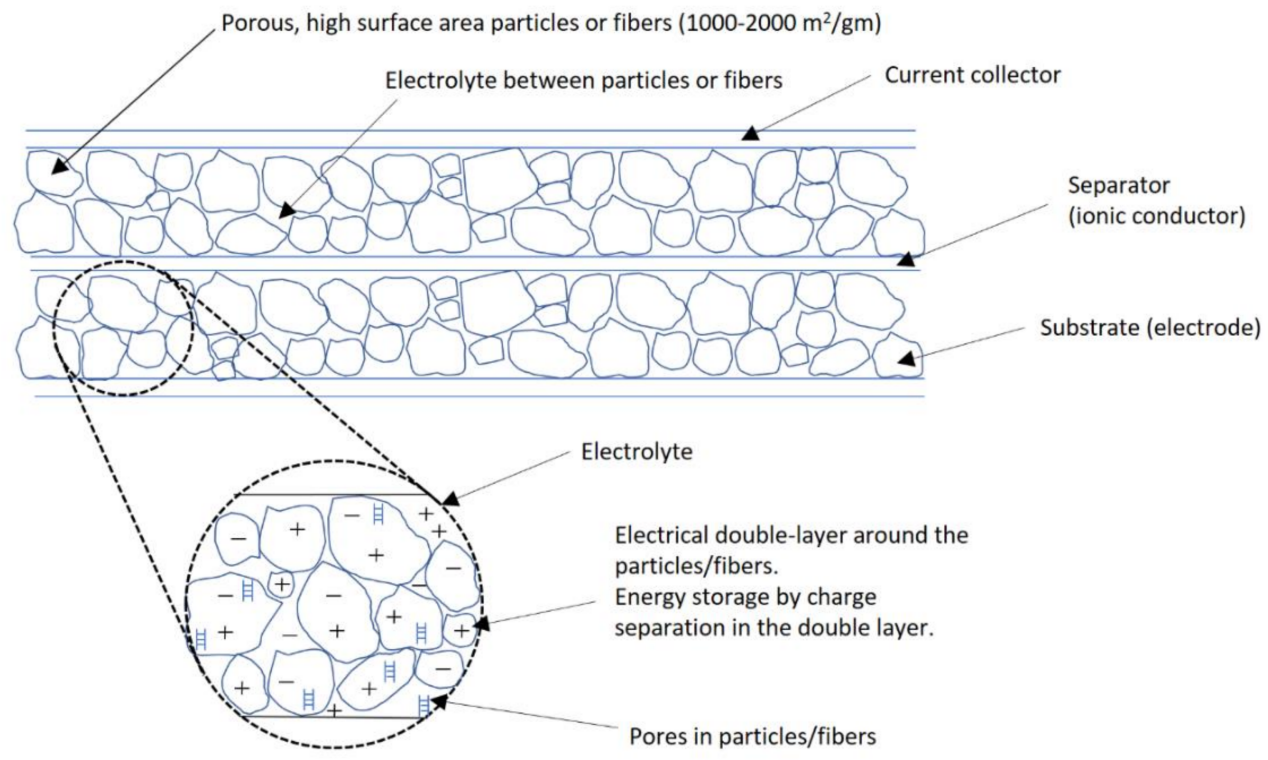

Figure 1. Schematic of an electric double-layer capacitor.

Most of the electrochemical capacitors commercially available use microporous activated carbon in both electrodes, and are termed electric double-layer capacitors (EDLCs). These devices are considered ideal ECCs in that by storing the electrical charge in the double layer, they can attain very high power capability $(>5 \mathrm{~kW} / \mathrm{kg}$ ) and extremely long cycle life ( $>1$ million deep discharge cycles). However, at present, EDLCs have energy densities of only 3-5 Wh/ $\mathrm{kg}$. This low energy density limits the applications for which the EDLCs can compete with batteries. Recent research [1,3,4] on EECs has focused on significantly improving their energy density. This can be done by increasing the specific capacitance $(\mathrm{F} / \mathrm{g})$ of the electrode materials and the rated (maximum) voltage of the cell for both EDLCs and other types of electrochemical capacitors.

Based on the weight of the active material in the electrodes, the energy density of an EDLC is given by:

$$
(\mathrm{Wh} / \mathrm{kg})_{\text {act.mat. }}=1 / 8(\mathrm{~F} / \mathrm{g})\left(\mathrm{V}_{\mathrm{r}}{ }^{2}-\mathrm{V}_{\min }{ }^{2}\right) / 3.6
$$

The resistance $\mathrm{R}$ of any EEC is difficult to calculate as it depends on the ionic conductivity of the electrolyte, the thickness and porosity of the electrodes, the electronic conductivity of the carbon and the contact resistance between the carbon particles and the current collector. The maximum power from a ECC can be calculated from $\mathrm{V}_{\mathrm{r}}{ }^{2} / 4 \mathrm{R}$, and its pulse power capability $(\mathrm{W} / \mathrm{kg})$ can be calculated [2] using:

$$
\begin{gathered}
\text { Pulse power }(\mathrm{W})=9 / 16\left(1-\eta_{\text {eff }}\right) V_{r}^{2 / R} \\
(\mathrm{~W} / \mathrm{kg})_{\text {pulse }}=3 / 2\left(1-\eta_{\text {eff }}\right)(\mathrm{Wh} / \mathrm{kg} / \mathrm{RC})(3600)
\end{gathered}
$$

where $R C$ is the time constant of the SC and $\eta_{\text {eff }}$ is the efficiency of the pulse.

The pulse power capability is proportional to the energy density and RC of the device. Many researchers use $V_{r}{ }^{2} / 4 R$ to rate the power capability of their devices, but the pulse power capability is a more realistic estimate for most applications. In many cases, an 
efficiency of $95 \%$ is used to calculate the power capability. Both capacitance and resistance can be determined from charge/discharge tests of devices.

Hybrid supercapacitors (HSC) are being developed [1-4] to increase the energy density. As shown in Figure 2, "hybrid" indicates that one of the electrodes is like those in an EDLC, and one is like an electrode in a battery.

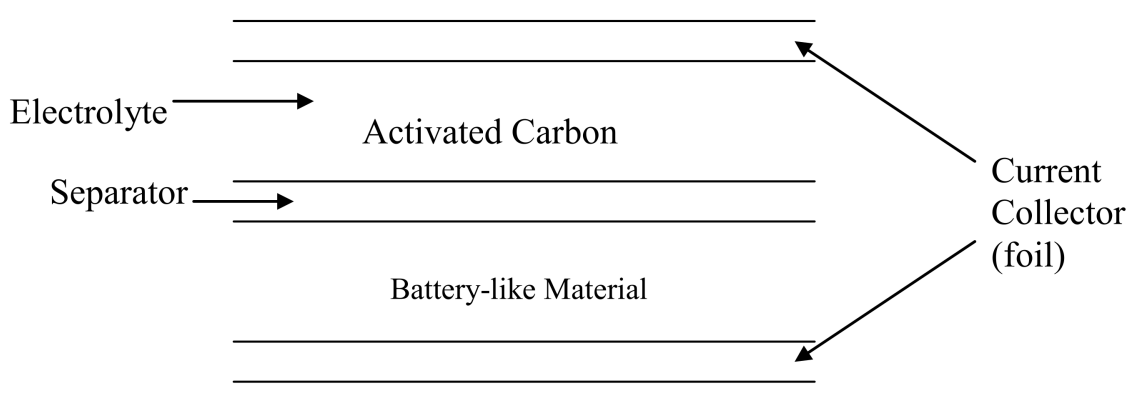

Figure 2. Schematic of an HSC electrochemical capacitor.

The energy stored in an HSC is dominated by the voltage of the battery-like electrode and the capacitance of the carbon electrode $[1,2]$.

$$
\begin{gathered}
\mathrm{E}_{\mathrm{HSC}, \text { act mat }}=\frac{1}{2}(\mathrm{~F} / \mathrm{g})_{\text {carb }} \mathrm{W}_{\text {carb }}\left[\mathrm{V}_{\max }{ }^{2}-\left(\mathrm{V}_{\max }-\Delta \mathrm{V}_{\text {carb }}\right)^{2}\right] \text { where } \Delta \mathrm{V}_{\text {carb }}=\mathrm{V}_{\max } / 2 \\
\mathrm{E}_{\mathrm{HSC}, \text { act mat }}=3 / 8(\mathrm{~F} / \mathrm{g})_{\text {carb }} \mathrm{W}_{\text {carb }} \mathrm{V}_{\text {max }}{ }^{2}
\end{gathered}
$$

The energy density of the HSC will be higher than that of EDLC devices using the same carbons and electrolyte, because the cell voltage will be higher and the carbon is used more efficiently. The resistance R of the HSC tends to be significantly higher than that of the EDLC because of the resistance of the battery-like electrode. As a result, the RC time constant of HSCs is higher, and the power density is lower than EDLCs. The same formula can be used to calculate the pulse power capacity of both HSCs and EDLCs.

The maximum voltage of the supercapacitors (SCs; ECC or HSC) is dependent primarily on the electrolyte used. The ionic conductivity of the electrolyte is an important factor in determining the resistance of the supercapacitors. The characteristics [5-7] of electrolytes that can be used in SCs are shown in Table 1.

\begin{tabular}{|c|c|c|c|c|}
\hline Electrolyte & 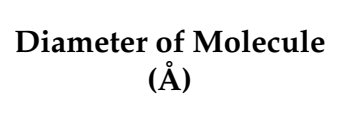 & $\begin{array}{l}\text { Density } \\
\left(\mathrm{g} / \mathrm{cm}^{3}\right)\end{array}$ & $\begin{array}{l}\text { Ionic Conductivity } \\
(\mathrm{mS} / \mathrm{cm})\end{array}$ & $\begin{array}{l}\text { Max Operating } \\
\text { Voltage } \\
\text { (V) }\end{array}$ \\
\hline \multicolumn{5}{|l|}{ Aqueous } \\
\hline $\mathrm{KOH}$ & 1.8 & 1.29 & 540 & 1 \\
\hline KCL & 1.8 & 1.09 & 210 & 1 \\
\hline $\mathrm{H}_{2} \mathrm{SO}_{4}$ & 2.9 & 1.2 & 750 & 1 \\
\hline $\mathrm{Na}_{2} \mathrm{SO}_{4}$ & 2.9 & 1.13 & 91 & $1.2-1.5$ \\
\hline $\mathrm{Li}_{2} \mathrm{SO}_{4}$ & 2.9 & 1.2 & 75 & $1.5-2.0$ \\
\hline $\mathrm{LiNO}_{3}$ & 2.6 & 1.2 & 150 & $1.5-2.0$ \\
\hline \multicolumn{5}{|l|}{ Organic } \\
\hline $\mathrm{TEABF}_{4} / \mathrm{PC}$ & $4-5$ & 1.2 & 15 & $2.5-3$ \\
\hline $\mathrm{TEABF}_{4} / \mathrm{CAN}$ & $4-5$ & 0.78 & 60 & $2.5-3$ \\
\hline \multicolumn{5}{|l|}{ Ionic liquids } \\
\hline Imidazolium/[EMIM $]^{+}\left[\mathrm{BF}_{4}\right]^{-}$ & $5-6$ & $1.3-1.5$ & $8(25 \mathrm{C})$ & 4.3 \\
\hline $\begin{array}{l}\text { Tetraalkylammonium }\left[\mathrm{nPrMe}_{3} \mathrm{~N}\right]^{+} \\
{\left[\mathrm{N}_{(}\left(\mathrm{CF}_{3} \mathrm{SO}_{2}\right)_{2}\right]^{-}}\end{array}$ & $5-6$ & $1.3-1.5$ & $1.4(25 \mathrm{C})$ & 5.3 \\
\hline Pyridinium/[BuPyr $]^{+}\left[\mathrm{BF}_{4}\right]^{-}$ & $4-5$ & $1.3-1.5$ & $1.9(25 \mathrm{C})$ & 3.4 \\
\hline $\begin{array}{l}\text { Piperidinium/[MePrPip }]^{+} \\
{\left[\mathrm{N}_{(}\left(\mathrm{CF}_{3} \mathrm{SO}_{2}\right)_{2}\right]^{-}}\end{array}$ & $4-5$ & $1.3-1.5$ & 1.5 & 5.6 \\
\hline
\end{tabular}

Table 1. The characteristics of various electrolytes used in supercapacitors. 
Most commercial SCs use organic electrolytes because, even for EDLCs, the rated voltages can be 2.5-3 V rather than 1-1.5 V for aqueous electrolytes. The higher rated voltages result in a much higher energy density than for devices using aqueous electrolytes. Aqueous electrolytes have much higher ionic conductivity than organic electrolytes, resulting in lower resistances in devices using aqueous electrolytes. Ionic liquid electrolytes (4-5 V) have much lower ionic conductivity than organic electrolytes, and for that reason ionic liquids have been used to a very limited extent in SCs, except for in high-temperature applications, even though they permit the design of devices with significantly higher rated voltages.

\section{Status and Future Development of Electrochemical Capacitors}

\subsection{Present Performance of Supercapacitors}

A summary of the characteristics of electrochemical capacitors that have been tested at UC Davis is given in Table 2. Both EDLC and hybrid HSC have been tested. The EDLC devices using activated carbon have rated voltages of 2.7-3.0 V and energy densities of 5-6 Wh/kg. EDLCs that use composites of carbon and graphene have energy densities of 8-9 Wh/kg. The power capability (W/ kg) ${ }_{95 \%}$ of most EDLCs is between 1000 and 2000, but there are devices with much higher power $(>3000 \mathrm{~W} / \mathrm{kg})$. The RC time constants of most EDLCs are between 1 and $2 \mathrm{~s}$, but high-power devices have time constants of $<0.5 \mathrm{~s}$. It is generally accepted that EDLCs using activated carbon have cycle lives of 500, 000 to 1 million deep discharge cycles at reasonable temperature $\left(<35^{\circ} \mathrm{C}\right)$.

Hybrid supercapacitors (HSC) have also been tested at UC Davis, as shown in Table 2. The energy densities of the hybrid supercapacitors are significantly higher than those of the EDLCs, varying from 10 to $60 \mathrm{Wh} / \mathrm{kg}$. The rated voltage of most of the HSCs is $3.8-4.0 \mathrm{~V}$. Most of the available HSCs use lithiated graphite in the negative electrode and activated carbon in the positive electrode. Yunasko uses a mixture of carbon and a metal oxide in both electrodes. Aowei-China has not disclosed the chemistry of their devices [8]. The power capability of the HSCs seems to be about the same as that of the EDLC devices, even though their RC time constants are much higher. Both JRS Micro and Aowei-China claim the cycle lives of their devices are comparable to those of EDLC devices. That is unexpected, and has not been confirmed by third parties. As shown by the linear $V$ vs. $t$ discharge profile in Figure 3, the Aowei cells show typical hybrid supercapacitor discharge behavior that is very different from batteries.

Table 2. Summary of the characteristics of available electrochemical capacitors.

\begin{tabular}{|c|c|c|c|c|c|c|c|c|c|}
\hline Device & $\begin{array}{c}\text { V } \\
\text { Rate }\end{array}$ & $\begin{array}{l}\mathrm{C} \\
(\mathrm{F})\end{array}$ & $\underset{(\mathrm{mOhm})^{\mathrm{c}}}{\mathrm{R}}$ & $\begin{array}{l}\mathrm{RC} \\
\text { (s) }\end{array}$ & Wh/kg ${ }^{a}$ & $\begin{array}{l}\text { W/kg } \\
(95 \%) b\end{array}$ & $\begin{array}{c}\text { W/kg } \\
\text { Match.Imped }^{d}\end{array}$ & $\begin{array}{l}\text { Weight } \\
\text { (kg) }\end{array}$ & $\begin{array}{l}\text { Vol. } \\
\text { (L) }\end{array}$ \\
\hline \multicolumn{10}{|l|}{ EDLCs } \\
\hline Maxwell & 2.7 & 2885 & 0.375 & 1.1 & 4.2 & 994 & 8836 & 0.55 & 0.414 \\
\hline Ioxus & 2.85 & 3095 & 0.33 & 1.0 & 5.0 & 1355 & 12,065 & 0.51 & 0.41 \\
\hline Skeleton Tech. & 2.85 & 3450 & 0.13 & 0.45 & 5.4 & 3353 & 29,809 & 0.52 & 0.39 \\
\hline Skeleton Tech. & 3.4 & 3200 & 0.48 & 1.5 & 8.9 & 1730 & 15,400 & 0.40 & 0.096 \\
\hline Skeleton Tech. & 3.0 & 3320 & 0.25 & 0.83 & 5.6 & 1878 & 17,310 & 0.54 & 0.39 \\
\hline Skeleton Tech. & 3.0 & 1900 & 0.52 & 0.98 & 4.9 & 1430 & 13,520 & 0.34 & 0.22 \\
\hline Skeleton Tech. & 2.85 & 4100 & 0.22 & 0.90 & 6.3 & 1956 & 19,230 & 0.53 & 0.39 \\
\hline Skeleton Tech & 3.0 & 5000 & 0.25 & 1.25 & 8.4 & 1783 & 15,845 & 0.568 & 0.39 \\
\hline Yunasko * & 2.75 & 1275 & 0.11 & 0.13 & 4.55 & 8791 & 78,125 & 0.22 & 0.15 \\
\hline DAE-China & 2.7 & 1668 & 0.6 & 1.0 & 6.2 & 1734 & 15,420 & 0.197 & 0.15 \\
\hline DAE-China & 2.7 & 990 & 1.8 & 1.78 & 4.9 & 801 & 6935 & 0.146 & 0.11 \\
\hline DAE-China & 2.7 & 412 & 3.7 & 1.52 & 4.1 & 791 & 7037 & 0.07 & 0.054 \\
\hline NessMaxwell & 3.0 & 3650 & 0.27 & 0.98 & 6.5 & 1875 & 16,666 & 0.50 & 0.394 \\
\hline Ness & 2.7 & 3160 & 0.4 & 1.3 & 4.4 & 982 & 8728 & 0.522 & 0.379 \\
\hline
\end{tabular}


Table 2. Cont.

\begin{tabular}{|c|c|c|c|c|c|c|c|c|c|}
\hline Device & $\begin{array}{c}\text { V } \\
\text { Rate }\end{array}$ & $\begin{array}{l}\mathrm{C} \\
(\mathrm{F})\end{array}$ & $\begin{array}{c}\mathrm{R} \\
(\mathrm{mOhm})^{\mathrm{c}}\end{array}$ & $\begin{array}{l}\mathrm{RC} \\
(\mathrm{s})\end{array}$ & $\mathrm{Wh} / \mathrm{kg}^{\mathrm{a}}$ & $\begin{array}{c}\text { W/kg } \\
(95 \%)\end{array}$ & $\begin{array}{c}\text { W/kg } \\
\text { Match.Imped }\end{array}$ & $\begin{array}{l}\text { Weight } \\
\text { (kg) }\end{array}$ & $\begin{array}{l}\text { Vol. } \\
\text { (L) }\end{array}$ \\
\hline \multicolumn{10}{|l|}{ Hybrid SC } \\
\hline Aowei-China & 3.8 & 10,000 & 2.0 & 20 & 40 & 1142 & 9162 & 0.197 & 0.14 \\
\hline Aowei-China & 4.1 & 10,000 & 2.0 & 20 & 65 & 1142 & 9162 & 0.197 & 0.14 \\
\hline DAE-China & 3.8 & 850 & 4.5 & 3.8 & 12.4 & 993 & 8828 & 0.087 & 0.062 \\
\hline Yunasko & 2.7 & 7200 & 1.4 & 10 & 26 & 1230 & 10,947 & 0.119 & 0.065 \\
\hline Yunasko & 2.7 & 3200 & 1.5 & 7.8 & 30 & 3395 & 30,200 & 0.068 & 0.038 \\
\hline JSR Micro & 3.8 & 2300 & 0.77 & 1.77 & 7.6 & 1366 & 12,200 & 0.387 & 0.214 \\
\hline JSR Micro & 3.8 & 1100 & 1.15 & 1.26 & 10 & 2450 & 21,880 & 0.144 & 0.077 \\
\hline
\end{tabular}

${ }^{a}$ Energy content at $400 \mathrm{~W} / \mathrm{kg}$ constant power, Vrated-1/2 Vrated; ${ }^{b}$ Power based on $\mathrm{P}=9 / 16 \times(1-\mathrm{EF}) \times \mathrm{V}_{\mathrm{o}}{ }^{2} / \mathrm{R}$, $\mathrm{EF}=$ efficiency of discharge; ${ }^{\mathrm{c}}$ Steady-state resistance including pore resistance; ${ }^{\mathrm{d}}$ Matched impedance power based on $\mathrm{P}=\mathrm{V}_{\mathrm{oc}}{ }^{2} / 4 \mathrm{R}_{\mathrm{DC}}$; All devices except those with * are packaged in metal/plastic containers.

\subsection{Test Data for Advanced Electrochemical Capacitors}

The Skeleton 5000 F EDLC and the Aowei-China 9000 F HSC have been tested at UC Davis. They are both advanced devices and are the best of their type in terms of energy density. The testing was done following the procedures described in $[9,10]$. The test data for the devices are given in Tables 3 and 4 . In both cases, the test data obtained at UC Davis agreed well with those claimed by the manufacturer of the devices. The test results of each of the devices will be used in Section 4 to model the performance of advanced SC in simulations for various vehicle applications. It can be anticipated that other companies than SkeletonTechnologies and Aowei-China will produce advanced ECC and HSC devices in the near future. This is especially true of the HSC devices.

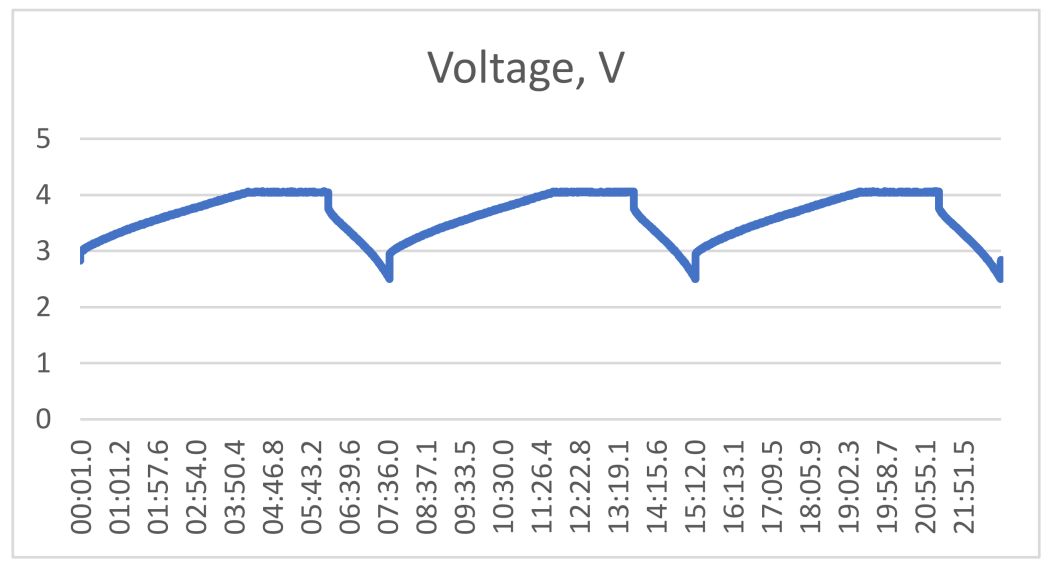

Figure 3. A constant current discharge trace of the $9000 \mathrm{~F}$ Aowei supercapacitor (V vs. $\mathrm{t}$ for $150 \mathrm{~A}$ discharge, $4.05-2.5 \mathrm{~V})$.

Table 3. Tests of the 5000 F Skeleton carbon/graphene supercapacitor.

\begin{tabular}{ccccc}
\hline \multicolumn{5}{c}{ Constant Current Tests } \\
\hline Current A & Time s & A s & C F & mOhm \\
\hline 60 & 126.3 & 7578 & 5056 & \\
100 & 74.3 & 7430 & 5061 & 0.25 \\
200 & 37.1 & 7420 & 5080 & 0.15 \\
300 & 23.7 & 7110 & 5042 & 0.25 \\
\hline
\end{tabular}


Table 3. Cont.

\begin{tabular}{ccccc}
\hline \multicolumn{5}{c}{ Constant Power Tests } \\
\hline Power W & W/kg & Time s & Wh & Wh/kg \\
\hline 80 & 140 & 215 & 4.77 & 8.4 \\
150 & 264 & 113 & 4.71 & 8.29 \\
300 & 528 & 55 & 4.58 & 8.06 \\
400 & 704 & 40 & 4,44 & 7.82
\end{tabular}

$\overline{\mathrm{RC}}=1.26 \mathrm{~s},(\mathrm{~W} / \mathrm{kg})_{95 \%}=1783$; Charge/discharge $3 \mathrm{~V}-1.5 \mathrm{~V}$, Charge $150 \mathrm{~A}$, hold $60 \mathrm{~s}$, Weight $0.568 \mathrm{~kg}$, Volume $0.39 \mathrm{~L}$.

Table 4. Test data for the Aowei 9000 F supercapacitor.

\begin{tabular}{|c|c|c|c|c|c|}
\hline \multicolumn{6}{|c|}{ Constant Current Tests } \\
\hline $\begin{array}{c}\text { Test } \\
\text { Conditions }\end{array}$ & Discharge Time s & Capac. F & $\begin{array}{l}\text { Resistance } \\
\text { mOhms }\end{array}$ & Wh & Wh/kg \\
\hline \multicolumn{6}{|c|}{ 3.8-2.8 $\mathrm{V}$ charge $100 \mathrm{~A}$ * } \\
\hline $50 \mathrm{~A}$ & 186 & 10,333 & 2.0 & 8.4 & 42 \\
\hline $100 \mathrm{~A}$ & 84 & 10,500 & 2.0 & 7.5 & 37.5 \\
\hline $150 \mathrm{~A}$ & 51 & 10,520 & 1.87 & 6.7 & 33.5 \\
\hline $200 \mathrm{~A}$ & 32 & 10,226 & 1.9 & 5.5 & 27.5 \\
\hline \multicolumn{6}{|c|}{$4.05-2.5 \mathrm{~V}$ charge $50 \mathrm{~A}$ ** } \\
\hline $50 \mathrm{~A}$ & 240 & 8955 & 4.2 & 14.7 & 73.5 \\
\hline $100 \mathrm{~A}$ & 138 & 10,615 & 2.5 & 12.3 & 61.5 \\
\hline $150 \mathrm{~A}$ & 91 & 10,748 & 1.93 & 11.9 & 59.5 \\
\hline $200 \mathrm{~A}$ & 64 & 11,034 & 1.95 & 11.0 & 55.0 \\
\hline \multicolumn{6}{|c|}{ Constant Power test Data for the Aowei 9000 F Supercapacitor } \\
\hline $\begin{array}{c}\text { Test } \\
\text { Conditions }\end{array}$ & Discharge Time s & W/kg & Wh & Wh/kg & $C_{\text {eff }}$ \\
\hline \multicolumn{6}{|c|}{$3.8-2.8 \mathrm{~V}$ charge $50 \mathrm{~A}$} \\
\hline $100 \mathrm{~W}$ & 312 & 500 & 8.67 & 44 & 9455 \\
\hline $200 \mathrm{~W}$ & 140 & 1000 & 7.78 & 39.5 & 8485 \\
\hline $300 \mathrm{~W}$ & 84 & 1500 & 7.0 & 35.5 & 7636 \\
\hline $400 \mathrm{~W}$ & 57 & 2000 & 6.33 & 32.1 & 6909 \\
\hline $500 \mathrm{~W}$ & 40 & 2500 & 5.55 & 28.2 & 6061 \\
\hline \multicolumn{6}{|c|}{ 4.05-2.5 V charge $50 \mathrm{~A}$ * } \\
\hline $100 \mathrm{~W}$ & $491 / 449$ & 500 & $13.6 / 12.47$ & $69 / 63.3$ & 9665 \\
\hline $200 \mathrm{~W}$ & $232 / 205$ & 1000 & $12.89 / 11.39$ & $65.4 / 57.8$ & 9143 \\
\hline $300 \mathrm{~W}$ & $139 / 123$ & 1500 & $11.58 / 10.25$ & $58.8 / 52.0$ & 8209 \\
\hline $400 \mathrm{~W}$ & missing & 2000 & - & - & - \\
\hline $500 \mathrm{~W}$ & $76 / 63$ & 2500 & $10.56 / 8.75$ & $53.6 / 44.4$ & 7480 \\
\hline
\end{tabular}

Cell weight $197 \mathrm{~g}, \mathrm{RC}=20 \mathrm{~s},(\mathrm{~W} / \mathrm{kg})_{95 \%}=1142 ;$ Resistance of cell measured using an impedance meter 1.15-1.25 mOhms; * 50 A charge was applied with a 120 s hold at charge cutoff voltage; ${ }^{* *} 100$ A charge was applied with a 60 s hold at charge cutoff voltage; Discharge cutoff voltage $2.5 / 2.8$.

\subsection{Projections of the Future Development of Advanced Supercapacitors}

A method of analysis was developed in [1] to project the performance of ECCs using advanced materials in terms of their energy and power characteristics. The method was implemented using Excel and applied to symmetric and asymmetric devices (EDLCs and hybrid HSC) using advanced carbons, metal oxides and polymer composites in the electrodes. The inputs for the calculations are based on available test data from the literature, which are summarized in $[9,10]$. The ECCs analyzed are unpackaged devices, but all other weights and volumes are considered. The resistances do not include interface and micro-pore resistances, but all others are included. The electrode material and electrolyte characteristics for each of the advanced ECs analyzed and the results of the performance 
calculations are shown in Table 5. The results for the performance of the devices are given in terms of both the weight of the active material in the cell and the total weight of the cell. The characteristics of small laboratory cells described in the literature are in most cases given in terms of the weight of the active material in the electrodes, which significantly overestimates the energy density and power capability potential of cells fabricated using the materials being studied. However, the present projections of the performance $(\mathrm{Wh} / \mathrm{kg}, \mathrm{Wh} / \mathrm{L}$, and $\left.(\mathrm{W} / \mathrm{kg})_{95 \%}\right)$ of the cells shown in Table 5 indicate that the future development of ECCs should yield devices with large improvements in performance. Key to the improvements in both EDLCs and hybrid supercapacitors will be the development of nano-carbons and graphene materials with high specific capacitance $(>200 \mathrm{~F} / \mathrm{g})$ in organic and ionic liquid electrolytes with ionic conductivity greater than $10 \mathrm{mS} / \mathrm{cm}$.

Table 5. Projected supercapacitor performance for various cell material designs.

\begin{tabular}{|c|c|c|c|c|c|c|c|c|}
\hline \multicolumn{9}{|c|}{ Supercap Type/Design } \\
\hline $\begin{array}{c}\text { EDLC } \\
\text { Symmetric } \\
\text { Carbon/carbon }\end{array}$ & $\begin{array}{l}\text { Electrode } \\
\text { Chemistry } \\
\text { Electrolyte }\end{array}$ & $\mathbf{V}$ & $\begin{array}{l}(\mathrm{Wh} / \mathrm{kg})_{\text {act }} \\
(\mathrm{Wh} / \mathrm{kg})_{\text {cell }}\end{array}$ & $(\mathrm{Wh} / \mathrm{L})_{\text {cell }}$ & $\begin{array}{l}(\mathrm{W} / \mathrm{kg})_{\text {cell }} \\
95 \% \text { eff. }\end{array}$ & $\begin{array}{l}(\mathrm{kW} / \mathrm{kg})_{\mathrm{act}} \\
\text { Mat.imped. }\end{array}$ & Ohm-cm & $\mathrm{RC} s$ \\
\hline $\begin{array}{l}\text { Activated Carbon } \\
\text { Aqueous } \mathrm{H}_{2} \mathrm{SO}_{4}\end{array}$ & $\begin{array}{c}150 \mathrm{~F} / \mathrm{g} \\
1.3 \mathrm{Ohm}-\mathrm{cm}\end{array}$ & $1-0.5$ & $\begin{array}{l}3.9 \\
0.9 \\
\end{array}$ & 1.9 & 4249 & 166.6 & 0.14 & 0.06 \\
\hline $\begin{array}{l}\text { Activated Carbon } \\
\text { Aqueous } \mathrm{Li}_{2} \mathrm{SO}_{4}\end{array}$ & $\begin{array}{c}200 \mathrm{~F} / \mathrm{g} \\
11 \mathrm{Ohm}-\mathrm{cm}\end{array}$ & $1.6-0.8$ & $\begin{array}{l}13.3 \\
2.21\end{array}$ & 4.8 & 706 & 37.7 & 1.2 & 0.84 \\
\hline $\begin{array}{c}\text { Activated Carbon } \\
\text { Organic ACN }\end{array}$ & $\begin{array}{c}80 \mathrm{~F} / \mathrm{g} \\
18 \mathrm{Ohm}-\mathrm{cm}\end{array}$ & $3-1.5$ & $\begin{array}{c}18.75 \\
6.97 \\
\end{array}$ & 9.64 & 2171 & 51.9 & 2.4 & 0.87 \\
\hline $\begin{array}{l}\text { Nano-carbon } \\
\text { Organic ACN }\end{array}$ & $\begin{array}{c}210 \mathrm{~F} / \mathrm{g} \\
18 \mathrm{Ohm}-\mathrm{cm}\end{array}$ & $3-1.5$ & $\begin{array}{l}49.2 \\
16.9\end{array}$ & 21.0 & 5353 & 138.0 & 1.1 & 0.86 \\
\hline $\begin{array}{l}\text { 3D Carbon } \\
\text { Ionic liquid }\end{array}$ & $\begin{array}{c}300 \mathrm{~F} / \mathrm{g} \\
116 \mathrm{Ohm}-\mathrm{cm}\end{array}$ & $4.1-2$ & $\begin{array}{r}175 \\
38.5\end{array}$ & 46.7 & 1855 & 75.1 & 7.8 & 4.2 \\
\hline $\begin{array}{l}\text { 3D Carbon } \\
\text { Organic ACN }\end{array}$ & $\begin{array}{c}300 \mathrm{~F} / \mathrm{g} \\
18 \mathrm{Ohm}-\mathrm{cm}\end{array}$ & $3-1.5$ & $\begin{array}{l}70.3 \\
20.6\end{array}$ & 39.1 & 1950 & 59.2 & 2.5 & 2.8 \\
\hline \multicolumn{9}{|c|}{ Hybrid SC Asym Graphite/Carbon } \\
\hline $\begin{array}{l}\text { Active Carbon } \\
\text { Lithiate Graphite } \\
\text { Organic ACN }\end{array}$ & $\begin{array}{c}80 \mathrm{~F} / \mathrm{g} \\
370 \mathrm{mAh} / \mathrm{g} \\
18 \mathrm{Ohm}-\mathrm{cm}\end{array}$ & $4-2$ & $\begin{array}{l}96.8 \\
35.6\end{array}$ & 55.1 & 6851 & 165.5 & 1.5 & 1.4 \\
\hline $\begin{array}{l}\text { 3D Carbon } \\
\text { LTO Carbon } \\
\text { Organic ACH }\end{array}$ & $\begin{array}{c}300 \mathrm{~F} / \mathrm{g} \\
150 \mathrm{mAH} / \mathrm{g} \\
18 \mathrm{Ohm}-\mathrm{cm}\end{array}$ & $3-1.5$ & $\begin{array}{c}155.7 \\
60.8\end{array}$ & 100.4 & 3962 & 90.3 & 1.5 & 4.2 \\
\hline $\begin{array}{l}\text { 3D Carbon } \\
\text { LI GRph with Sic } \\
\text { Ionic liquid }\end{array}$ & $\begin{array}{c}300 \mathrm{~F} / \mathrm{g} \\
600 \mathrm{mAh} / \mathrm{g} \\
116 \mathrm{Ohm}-\mathrm{cm}\end{array}$ & $4.1-2$ & $\begin{array}{l}356 \\
74.1\end{array}$ & 157.8 & 4079 & 174.2 & 3.5 & 4.7 \\
\hline \multicolumn{9}{|c|}{ Hybrid SC Asym Metal Oxide/Carbon } \\
\hline $\begin{array}{c}\text { Carbon } \mathrm{CuO} \\
\text { Nano-graphene } \\
\text { Aqueous } \mathrm{KOH}\end{array}$ & $\begin{array}{c}950 \mathrm{~F} / \mathrm{g} \\
200 \mathrm{~F} / \mathrm{g} \\
2 \mathrm{Ohm}-\mathrm{cm}\end{array}$ & $1.6-0.8$ & $\begin{array}{l}26.5 \\
12.2\end{array}$ & 30.1 & 2600 & 50.11 & 0.35 & 0.82 \\
\hline $\begin{array}{c}\text { Carbon } \mathrm{MgO} \\
\text { Nano-graphene } \\
\text { Aqueous } \mathrm{KOH}\end{array}$ & $\begin{array}{c}300 \mathrm{~F} / \mathrm{g} \\
210 \mathrm{~F} / \mathrm{g} \\
2 \mathrm{Ohm}-\mathrm{cm}\end{array}$ & $1.6-0.8$ & $\begin{array}{c}13.8 \\
6.2\end{array}$ & 18.5 & 4171 & 82.6 & 0.26 & 0.26 \\
\hline $\begin{array}{l}\text { Carbon } \mathrm{CuO} \\
\text { 3D Carbon } \\
\text { Ionic Liquid }\end{array}$ & $\begin{array}{c}950 \mathrm{~F} / \mathrm{g} \\
300 \mathrm{~F} / \mathrm{g} \\
116 \mathrm{ohm}-\mathrm{cm}\end{array}$ & $4-2$ & $\begin{array}{l}271 \\
83.4\end{array}$ & 316 & 1086 & 31.4 & 1.5 & 1.42 \\
\hline
\end{tabular}


Table 5. Cont.

\begin{tabular}{|c|c|c|c|c|c|c|c|c|}
\hline \multicolumn{9}{|c|}{ Supercap Type/Design } \\
\hline $\begin{array}{c}\text { EDLC } \\
\text { Symmetric } \\
\text { Carbon/carbon }\end{array}$ & $\begin{array}{l}\text { Electrode } \\
\text { Chemistry } \\
\text { Electrolyte }\end{array}$ & $\mathbf{V}$ & $\begin{array}{l}(\mathrm{Wh} / \mathrm{kg})_{\text {act }} \\
(\mathrm{Wh} / \mathrm{kg})_{\text {cell }}\end{array}$ & $(\mathrm{Wh} / \mathrm{L})_{\text {cell }}$ & $\begin{array}{c}(\mathrm{W} / \mathrm{kg})_{\text {cell }} \\
95 \% \text { eff. }\end{array}$ & $\begin{array}{l}(\mathrm{kW} / \mathrm{kg})_{\mathrm{act}} \\
\text { Mat.imped. }\end{array}$ & Ohm-cm & $\mathrm{RC} s$ \\
\hline \multicolumn{9}{|c|}{ Hybrid SC Asymmetric Polymers } \\
\hline $\begin{array}{l}\text { P doped pMet Comp } \\
\text { N doped pMet comp } \\
\text { Organic PC }\end{array}$ & $\begin{array}{c}240 \mathrm{~F} / \mathrm{g} \\
180 \mathrm{~F} / \mathrm{g} \\
65 \mathrm{ohm}-\mathrm{cm}\end{array}$ & $3-1.5$ & $\begin{array}{c}65 \\
24.1 \\
\end{array}$ & 44.6 & 2102 & 50.4 & 4.5 & 3.8 \\
\hline $\begin{array}{l}\text { P doped pMet comp } \\
\text { Active Carbon } \\
\text { Organic PC }\end{array}$ & $\begin{array}{c}240 \mathrm{~F} / \mathrm{g} \\
120 \mathrm{~F} / \mathrm{g} \\
65 \mathrm{Ohm}-\mathrm{cm}\end{array}$ & $3-1.5$ & $\begin{array}{l}54.1 \\
21.8\end{array}$ & 40.9 & 1009 & 22.2 & 0.8 & 1.8 \\
\hline Carbon & $\begin{array}{c}800 \mathrm{~F} / \mathrm{g} \\
180 \mathrm{~F} / \mathrm{gm} \\
12 \mathrm{Ohm}-\mathrm{cm}\end{array}$ & $1.6-0.8$ & $\begin{array}{l}53.4 \\
15.3\end{array}$ & 29.4 & 1557 & 48.3 & 0.8 & 1.8 \\
\hline $\begin{array}{l}\text { P doped pMet comp } \\
\text { 3D Nano-carbon } \\
\text { Ionic Liquid }\end{array}$ & $\begin{array}{c}900 \mathrm{~F} / \mathrm{g} \\
300 \mathrm{~F} / \mathrm{g} \\
116 \mathrm{ohm}-\mathrm{cm}\end{array}$ & $4-2$ & $\begin{array}{l}354 \\
58.7\end{array}$ & 110.8 & 1866 & 100.1 & 3.6 & 1.88 \\
\hline
\end{tabular}

\section{Vehicle Applications of Supercapacitors}

In this section of the paper, applications of supercapacitors are evaluated based on Advisor [11] simulations of hybrid-electric vehicles, from compact passenger cars to long haul trucks. Special attention is given to the use of the advanced ECCs discussed in the previous sections. The fuel economy of vehicles utilizing hybrid-electric (HEV), plug-in hybrid (PHEV), and hydrogen fuel cell (FCV) powertrains are analyzed using lithium batteries and EECs in place of the batteries. The supercapacitors can be used alone in the $\mathrm{HEV}$ and FCV powertrains and in combination with lithium batteries in the PHEVs.

\subsection{Hybrid-Electric Vehicles (HEVs)}

The application of supercapacitors in hybrid-electric passenger cars has been studied at the University of California, Davis in the past [12-16]. A summary of Advisor simulation results for a mid-size passenger car taken from [12] is shown in Table 6. These results indicate that large improvements in fuel economy in city driving can be expected in both mild and micro-hybrids with supercapacitors that store relatively small quantities of energy (less than $200 \mathrm{Wh}$ ). In most cases, the capacitors used in the previous simulations were of the carbon/carbon EDLC type, having energy densities of 4-5 Wh $/ \mathrm{kg}$ (see Table 2). The electric motors were small ( 4 and $20 \mathrm{~kW}$ ). The IC gasoline engines used were not as efficient as expected in future engines, so the baseline fuel economy of the reference mid-size car was relatively low $(25-36 \mathrm{mpg})$. It is of interest to evaluate the use of the advanced supercapacitors in HEVs for a wide range of car, SUV, and truck types with more advanced gasoline and diesel engines. This was done in the present study. 
Table 6. Mild and Micro-HEV Advisor simulation results using various supercapacitors [12].

\begin{tabular}{|c|c|c|c|c|c|}
\hline Energy Storage System & $\begin{array}{l}\text { Weight of the } \\
\text { Ultracaps. } \\
(\mathrm{kg})^{*}\end{array}$ & $\begin{array}{l}\text { Energy } \\
\text { Stored }\end{array}$ & $\begin{array}{c}\text { mpg } \\
\text { FUDS }\end{array}$ & $\begin{array}{c}\text { mpg } \\
\text { FEDHW }\end{array}$ & $\begin{array}{l}\text { mpg } \\
\text { US06 }\end{array}$ \\
\hline \multicolumn{6}{|l|}{ Mild HEV 20 kW motor } \\
\hline$Y_{1}$ unghrid & 12 & $300 \mathrm{Wh}$ & 47.4 & 46.5 & 32.2 \\
\hline Yunasko hybrid & 6 & $150 \mathrm{Wh}$ & 45.3 & 46.0 & 31.6 \\
\hline JM Energy hybrid & 11 & $100 \mathrm{Wh}$ & 47.8 & 47.2 & 31.9 \\
\hline Yunasko C/C & 22 & $100 \mathrm{Wh}$ & 46.0 & 46.4 & 31.6 \\
\hline Maxwell C/C & 28 & $100 \mathrm{Wh}$ & 47.2 & 47.5 & 32.2 \\
\hline Skeleton 2014 C/C 3200F & 13 & 115 & 47.8 & 47.0 & 31.9 \\
\hline High power LiTiO battery & 14 & 1120 & 40.6 & 40.3 & 30.5 \\
\hline $\begin{array}{l}\text { ICE Ford Focus engine } \\
120 \mathrm{~kW}\end{array}$ & & & 25.5 & 36.8 & 26.8 \\
\hline $\begin{array}{l}\text { Fuel economy } \\
\text { improvement }\end{array}$ & & & $80 \%$ & $27 \%$ & $19 \%$ \\
\hline Micro start stop HEV & \multicolumn{5}{|c|}{ Supercap with a lead-acid battery, $4 \mathrm{~kW}$ electric motor } \\
\hline & $5 \mathrm{~kg}$ & $150 \mathrm{Wh}$ & 32.4 & 41.4 & 28.9 \\
\hline Yunasko hybrid & $3 \mathrm{~kg}$ & $75 \mathrm{Wh}$ & 32.1 & 41.2 & 28.5 \\
\hline Yunasko C/C & $11 \mathrm{~kg}$ & $50 \mathrm{Wh}$ & 32.2 & 41.2 & 28.6 \\
\hline Maxwell C/C & $12 \mathrm{~kg}$ & $50 \mathrm{Wh}$ & 32.3 & 41.3 & 28.3 \\
\hline Skeleton C/C 3200F & 5 & $50 \mathrm{Wh}$ & 33.1 & 40.2 & 28.0 \\
\hline $\begin{array}{l}\text { Fuel economy } \\
\text { improvement }\end{array}$ & & & $26 \%$ & $12 \%$ & $7 \%$ \\
\hline
\end{tabular}

Advisor HEV simulations were run in this study for compact and mid-size cars, small and large SUVs, a delivery van, and Class 7 Box and Class 8 long haul trucks. For each vehicle type, a simulation was performed for a lithium battery, an EDLC Skeleton Tech capacitor, and the two Aowei hybrid capacitors. The characteristics of the energy storage devices used in the vehicle simulations are summarized in Table 7. The characteristics shown for each energy storage device are based on testing those devices at UC Davis. In the case of the ECCs, the characteristics are based on those shown in Table 2. As indicated in Table 7, the resistance of the Aowei $4.1 \mathrm{~V}$ device was reduced to half the measured value. In the case of the lithium battery, the characteristics are based on test data for NMC cells. NMC cells are available with higher power (lower resistance) but lower energy density than those values shown in Table 7.

Table 7. Characteristics of the energy storage device used in the simulations.

\begin{tabular}{ccccc}
\hline Storage Technology & Voltage $\mathbf{V}_{\mathbf{r}}$ & $\begin{array}{c}\text { Energy Density } \\
\text { Wh/kg }\end{array}$ & Density Kg/L & $\begin{array}{c}\text { Power Capacity } \\
\text { (W/kg) } \mathbf{9 5}_{\mathbf{5}}\end{array}$ \\
\hline $\begin{array}{c}\text { NCM lithium battery } \\
\text { EDLC capacitor }\end{array}$ & 4.2 & 161 & 2.5 & 485 \\
$\begin{array}{c}\text { Skeleton } \\
\text { Aowei hybrid } \\
\text { capacitor 3.8 V }\end{array}$ & 3.0 & 8.2 & 1.4 & 1783 \\
$\begin{array}{c}\text { Aowei hybrid } \\
\text { capacitor 4.1 V }\end{array}$ & 3.8 & 40 & 1.4 & 1142 \\
\hline
\end{tabular}

The energy storage device in each simulation was sized (Wh) such that the simulation showed a round-trip efficiency of close to $90 \%$ on the city and highway driving cycles. A high round-trip efficiency is needed to achieve close to the maximum improvement in fuel economy by hybridizing the vehicle powertrain. The HD trucks were run on the HHDDTtransient and cruise driving cycles, and the other vehicle types were run on the FUDS and Fed-highway cycles. The maximum power of the electric motor in the powertrain was varied from $30 \mathrm{~kW}$ for the compact car to $200 \mathrm{~kW}$ for the long haul truck. The general 
control strategy $[13,14]$ for the HEV powertrain is that the electric motor provides the power demanded alone when possible, and when the SOC of the energy storage device permits. When that is not possible, the engine provides the power demanded by the vehicle and recharges the energy storage device. This strategy results in the engine operating at high efficiency nearly all the time. The engine maps used in the simulations assumed maximum engine efficiencies of $38 \%$ for gasoline engines and $44 \%$ for diesel engines.

The results of the simulations for each of the vehicles are shown in Table 8. City and highway fuel economy results are shown in the table for each vehicle type and energy storage device. Advisor output graphics for several HEVs are shown in Figure 4, comparing the results for the operation of the vehicle with the lithium battery and the $4.1 \mathrm{~V}$ supercapacitor on the FUDS cycle. The energy storage units were sized such that their round-trip efficiency on the simulated driving cycles were close to $90 \%$. For all vehicle types, the weight and volume of the capacitors decreased in the expected order: EDLC, hybrid $3.8 \mathrm{~V}$, hybrid $4.1 \mathrm{~V}$. The $4.1 \mathrm{~V}$ hybrid capacitor in all cases was lighter and smaller than the lithium battery, and its energy storage capacity was lower by a factor of 5-6. The fuel economies of the HEVs on the FUDS cycle were significantly higher (30-50\%) than that of the corresponding ICE vehicle, except for the long haul truck, for which the fuel economy improvement was $20 \%$. The effect of hybridizing on fuel economy on the highway cycles was small, being at most $10 \%$, but it was much less in most cases. The effect on the highway fuel economy of the long haul truck was 4-6\%. In almost all cases, the fuel economy improvement was highest when using the $4.1 \mathrm{~V}$ hybrid capacitor.

Table 8. Summary of the Advisor HEV simulation results and key inputs.

\begin{tabular}{|c|c|c|c|c|c|c|c|}
\hline & kg & $\mathbf{L}$ & Wh & EM kW & Mpg * FUDS & Mpg ** Highway & Efficiency \% \\
\hline \multicolumn{8}{|l|}{ Compact car } \\
\hline ICE gasoline & & & & & 42.5 & 53.7 & \\
\hline Lithium battery & 16 & 6.4 & 2600 & 30 & $\begin{array}{l}52.3 \\
(23)\end{array}$ & 50.6 & 88 \\
\hline EDLC Skeleton & 25 & 17.9 & 205 & & $\begin{array}{l}58.7 \\
(38)\end{array}$ & $\begin{array}{c}58.2 \\
(5)\end{array}$ & 95 \\
\hline Aowei $3.8 \mathrm{~V}$ & 11 & 7.9 & 440 & & 56.2 & 56.8 & 90 \\
\hline Aowei $4.1 \mathrm{~V}$ & 8 & 5.7 & 520 & & $\begin{array}{l}56.8 \\
(34)\end{array}$ & $\begin{array}{l}58.6 \\
(9.1) \\
\end{array}$ & 89 \\
\hline \multicolumn{8}{|l|}{ Mid-size car } \\
\hline ICE gasoline & & & & & 34.7 & 46 & \\
\hline Lithium battery & 28 & 11.2 & 4508 & 40 & $\begin{array}{c}49 \\
(41) \\
\end{array}$ & $\begin{array}{c}47 \\
(2.2) \\
\end{array}$ & 89 \\
\hline EDLC Skeleton & 34 & 24.3 & 279 & & $\begin{array}{l}54.8 \\
(58)\end{array}$ & $\begin{array}{l}47.5 \\
(3.2) \\
\end{array}$ & 95 \\
\hline Aowei $3.8 \mathrm{~V}$ & 18 & 12.9 & 720 & & 52.9 & 48.2 & 90 \\
\hline Aowei $4.1 \mathrm{~V}$ & 12 & 8.6 & 780 & & $\begin{array}{l}54.9 \\
(58)\end{array}$ & $\begin{array}{l}48.8 \\
(6.1)\end{array}$ & $94(1 / 2 R)$ \\
\hline Small SUV & & & & 40 & & & \\
\hline ICE gasoline & & & & & 35.3 & 44.7 & \\
\hline Lithium battery & 25 & 10 & 4025 & & $\begin{array}{c}51 \\
(45)\end{array}$ & 43.3 & 87 \\
\hline EDLC Skeleton & 34 & 24.2 & 279 & & $\begin{array}{l}53.2 \\
(51)\end{array}$ & $\begin{array}{c}46 \\
(2.8)\end{array}$ & 95 \\
\hline
\end{tabular}


Table 8. Cont.

\begin{tabular}{|c|c|c|c|c|c|c|c|}
\hline & kg & $\mathbf{L}$ & Wh & EM kW & Mpg * FUDS & Mpg ** Highway & Efficiency $\%$ \\
\hline Aowei $3.8 \mathrm{~V}$ & 13 & 9.3 & 520 & & 52.5 & 44.8 & 89 \\
\hline Aowei $4.1 \mathrm{~V}$ & 10 & 7.1 & 650 & & $\begin{array}{l}54.1 \\
(53)\end{array}$ & $\begin{array}{l}46.5 \\
(4.0) \\
\end{array}$ & $93(1 / 2 R)$ \\
\hline \multicolumn{8}{|l|}{ Large SUV } \\
\hline ICE gasoline & & & & & 17.9 & 25.5 & \\
\hline Lithium battery & 37 & 14.8 & 5957 & 60 & $\begin{array}{c}26 \\
(45)\end{array}$ & 22 & 88 \\
\hline EDLC Skeleton & 56 & 40 & 459 & & $\begin{array}{l}30.3 \\
(69)\end{array}$ & 23.9 & 95 \\
\hline Aowei $3.8 \mathrm{~V}$ & 22 & 15.7 & 880 & & 30 & 22.8 & 91 \\
\hline Aowei $4.1 \mathrm{~V}$ & 15 & 10.7 & 975 & & $\begin{array}{c}32 \\
(79)\end{array}$ & 23.4 & $94(1 / 2 R)$ \\
\hline \multicolumn{8}{|l|}{ Delivery van } \\
\hline ICE diesel & & & & & 12.8 & 12.7 & \\
\hline Lithium battery & 53 & 21.2 & 8533 & 100 & $\begin{array}{l}15.6 \\
(22)\end{array}$ & $\begin{array}{l}13.2 \\
(3.9)\end{array}$ & 85 \\
\hline EDLC Skeleton & 43 & 30.7 & 353 & & $\begin{array}{c}19 \\
(48)\end{array}$ & 16.6 & 93 \\
\hline Aowei $3.8 \mathrm{~V}$ & 35 & 25 & 1400 & & 18.4 & 15.9 & 87 \\
\hline Aowei $4.1 \mathrm{~V}$ & 25 & 17.9 & 1625 & & $\begin{array}{l}18.3 \\
(43)\end{array}$ & 16.6 & $92(1 / 2 R)$ \\
\hline \multicolumn{8}{|l|}{ Class 7 box trk } \\
\hline ICE diesel & & & & & 6 & 9.9 & 85 \\
\hline Lithium battery & 98 & 39.2 & 15,778 & 200 & $\begin{array}{c}9.9 \\
(65)\end{array}$ & 9.0 & 85 \\
\hline EDLC Skeleton & 85 & 60.7 & 697 & & $\begin{array}{c}9.0 \\
(50)\end{array}$ & $\begin{array}{c}10.1 \\
(2)\end{array}$ & 93 \\
\hline Aowei $3.8 \mathrm{~V}$ & 50 & 35.7 & 2000 & & 9.2 & 9.4 & 87 \\
\hline Aowei $4.1 \mathrm{~V}$ & 30 & 21.4 & 1950 & & $\begin{array}{c}9.2 \\
(53)\end{array}$ & $\begin{array}{l}10.0 \\
(11)\end{array}$ & $92(1 / 2 R)$ \\
\hline \multicolumn{8}{|l|}{ Long haul truck } \\
\hline ICE Diesel & & & & & 4.0 & 6.9 & \\
\hline Lithium battery & 135 & 54 & 21,735 & 250 & $\begin{array}{c}4.9 \\
(23)\end{array}$ & 6.6 & 84 \\
\hline EDLC Skeleton & 114 & 81.4 & 935 & & $\begin{array}{c}4.8 \\
(20) \\
\end{array}$ & $\begin{array}{c}7.3 \\
(5.8)\end{array}$ & 93 \\
\hline Aowei $3.8 \mathrm{~V}$ & 74 & 52.9 & 2960 & & 5.0 & 7.1 & 88 \\
\hline Aowei $4.1 \mathrm{~V}$ & 44 & 40 & 2860 & & $\begin{array}{c}4.8 \\
(20)\end{array}$ & $\begin{array}{c}7.2 \\
(4.4)\end{array}$ & $90(1 / 2 \mathrm{R})$ \\
\hline
\end{tabular}

* All city driving cycles are FUDS except for HD trucks, which are HHDDT-transient. ${ }^{* *}$ All highway cycles are FED-HW except for HD trucks, which are HHDDT-cruise.

Supercapacitors have not been used in the past in hybrid vehicles both because their energy density has been too low and their cost much too high. The development of the HSC devices has mitigated the energy density problem, and it is interesting to consider the 
cost issue by estimating the cost of the $4.1 \mathrm{~V}$ hybrid capacitor. This can be done using the simple relationship [1]

$$
\mathrm{USD} / \mathrm{Wh}=\mathrm{USD} / \mathrm{kg} / \mathrm{Wh} / \mathrm{kg}
$$

using as a baseline capacitor a $2.7 \mathrm{~V} 3000 \mathrm{~F}$ carbon/carbon EDLC having an energy density of $4.5 \mathrm{Wh} / \mathrm{kg}$ and selling for 0.25 cents $/ \mathrm{F}$, with $\mathrm{Wh}=2.28$, wt. $0.55 \mathrm{~kg}$, cost USD 7.5, USD $13.6 / \mathrm{kg}$ and USD/Wh 3.29. If the energy density of the hybrid capacitor is $65 \mathrm{Wh} / \mathrm{kg}$ and its USD $/ \mathrm{kg}$ is the same as the baseline EDLC, the USD/Wh of the hybrid capacitor would be $13.6 / 65=0.210$ or USD $210 / \mathrm{kWh}$. Since the $4.1 \mathrm{~V}$ hybrid capacitor stores less energy by a factor of 5-6, the cost of the capacitor would be less than that of the lithium battery in the various HEVs. This result indicates that cost may not be an issue in using HSC devices in HEVs in the future.

The simulation results shown in Table 8 indicate that the use of ECCs results in fuel economy improvements in most cases greater than with lithium batteries. There has not been a lot of published data on the fuel economy of vehicles using ECCs for energy storage. However, the test results given in [17-19] from NREL show that there is every reason to believe that ECCs will function very well in place of batteries in HEVs. In the NREL program, the nickel metal hydride battery in an HEV Saturn Vue was replaced by JSR Micro HSC (see Table 2). In-vehicle testing showed that the fuel economy of the vehicle with supercapacitors $(180 \mathrm{Wh})$ was in all tests at least as high as that with the batteries. The laboratory bench testing of HEV energy storage systems at NREL also showed that the supercapacitors functioned as projected in the simulations.

\section{HEV mid-size passenger car with the lithium battery on the FUDS}
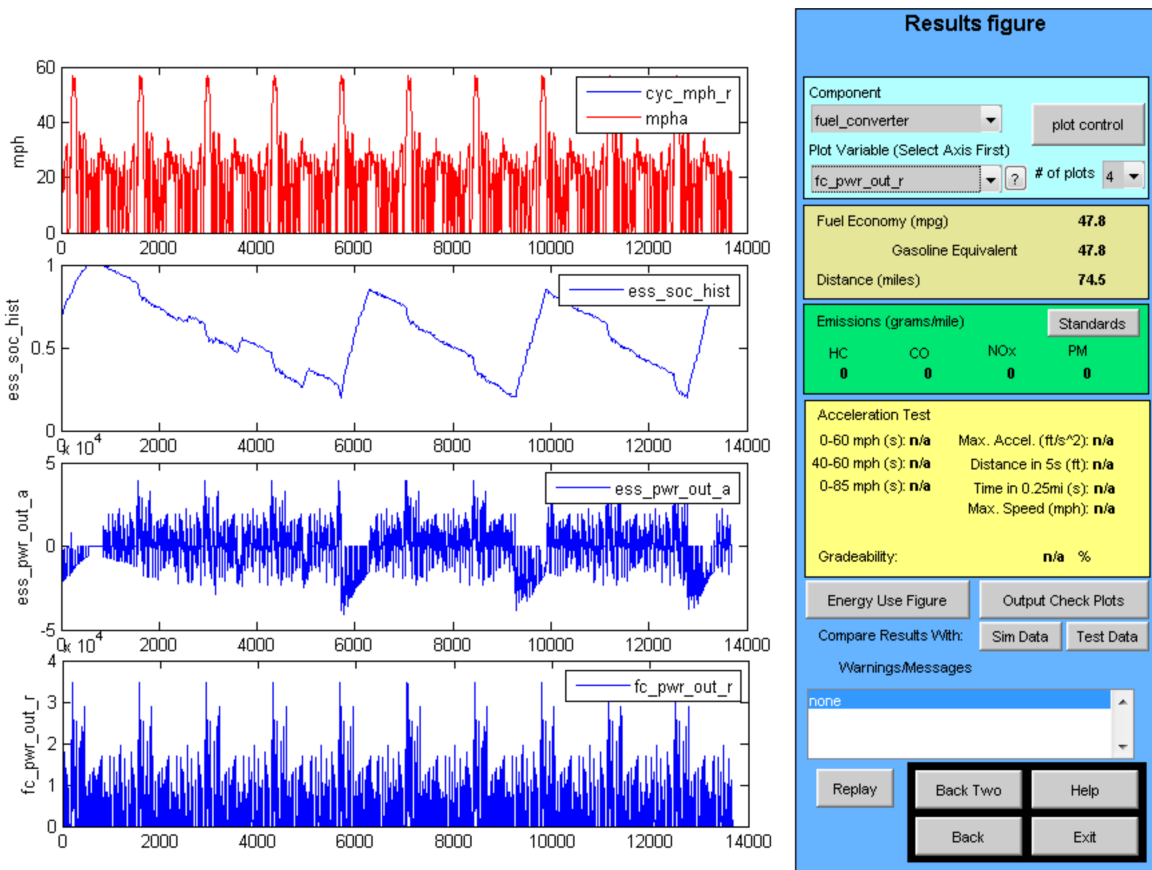

HEV mid-size passenger car with $4.1 \mathrm{~V}$ supercapacitor on the FUDS

Figure 4. Cont. 

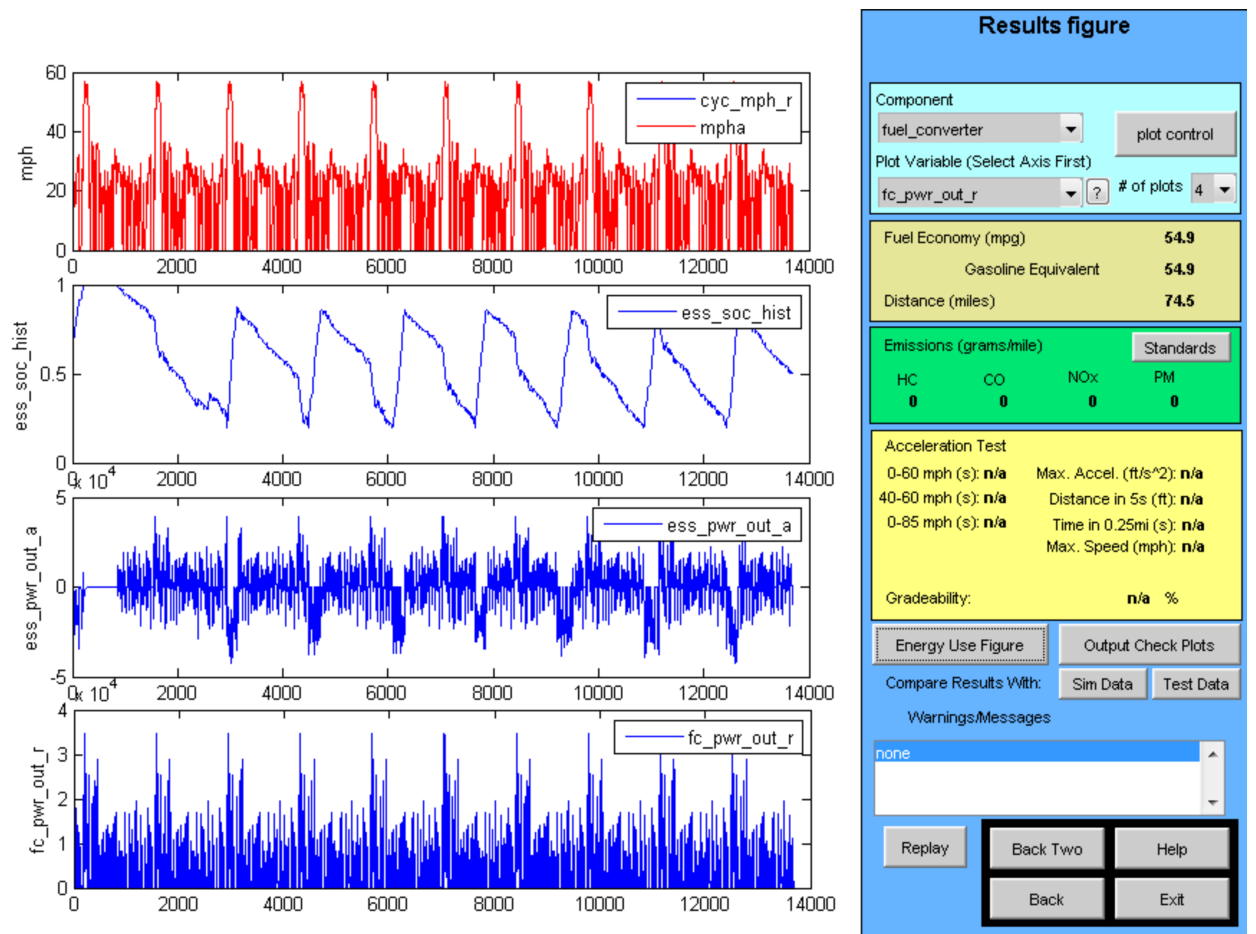

HEV delivery van with lithium battery on the FUDS
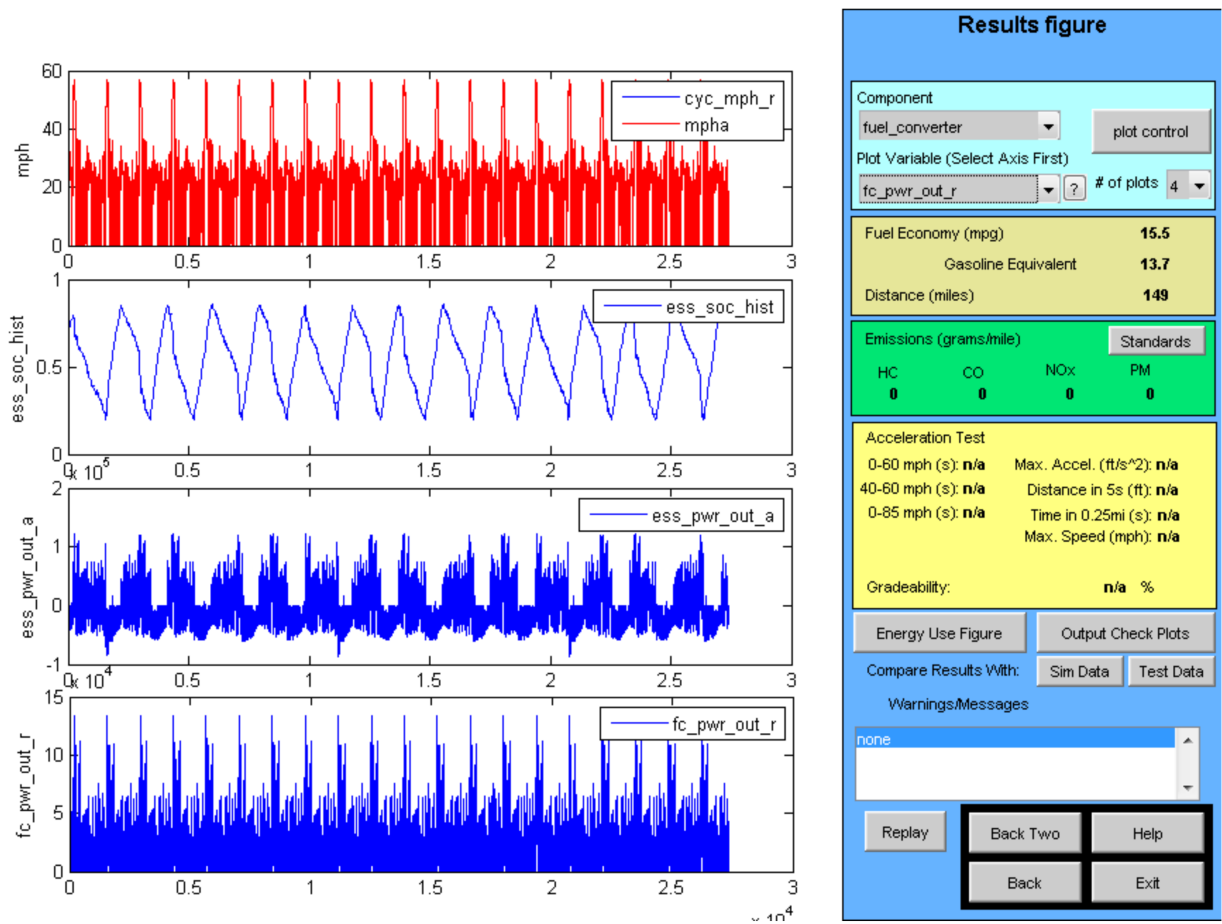

Figure 4. Advisor output graphics for the mid-size passenger car and city delivery van operating as HEVs.

\subsection{Plug-in Hybrid Vehicles (PHEVs)}

Advisor simulations were also run for PHEVs using supercapacitors. The PHEVs operate as an EV until the main storage battery is depleted, and as an HEV for further driving. The PHEVs simulated were set up with a supercapacitor to assist the main storage battery during periods of high power demand, and then to operate independently of the battery in the HEV mode. Hence the PHEV fuel economy in the HEV mode would be 
essentially that shown in Table 8 for each type of vehicle. The use of the supercapacitor to assist the main storage battery will permit it to be optimized for energy density rather than power. As shown in $[15,16]$, this will reduce the size and cost of the main battery and extend its cycle life. Advisor output graphics of PHEVs operating in the EV and HEV modes are shown in Figure 5 for a small SUV and a Class 8 box truck.

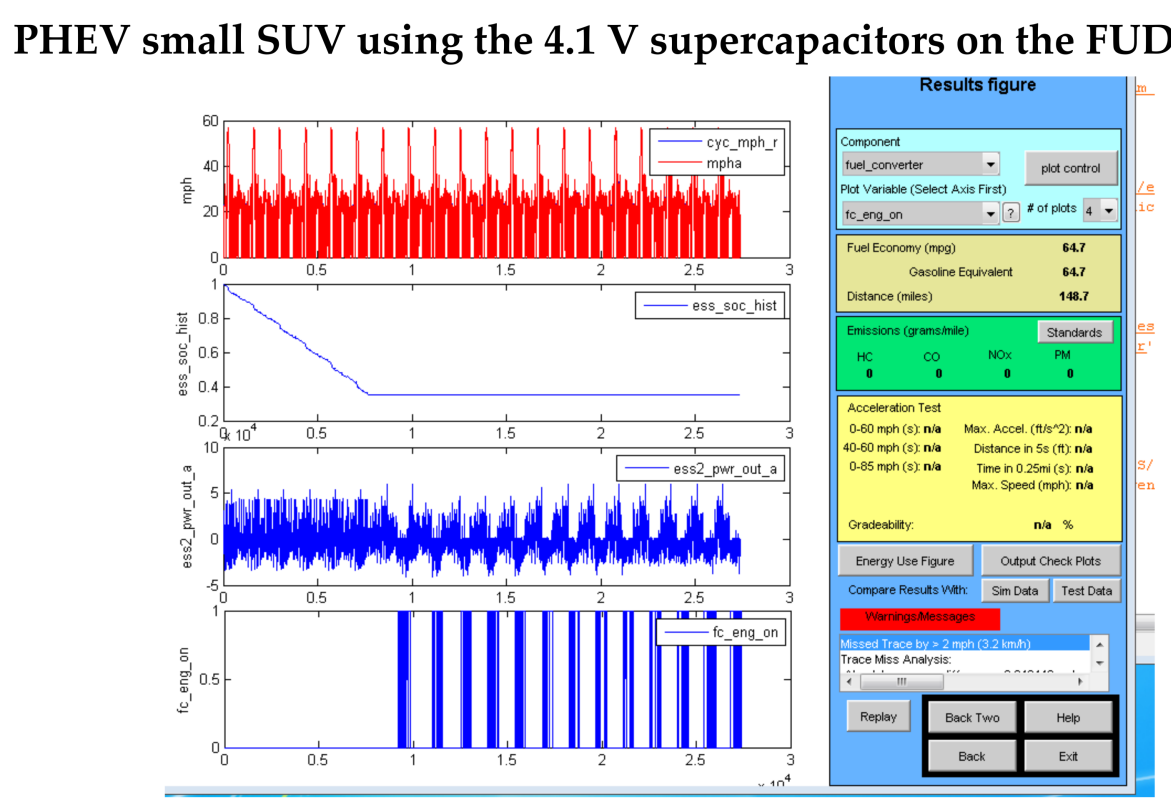

PHEV Class 8 box truck on HDDT-transient cycle

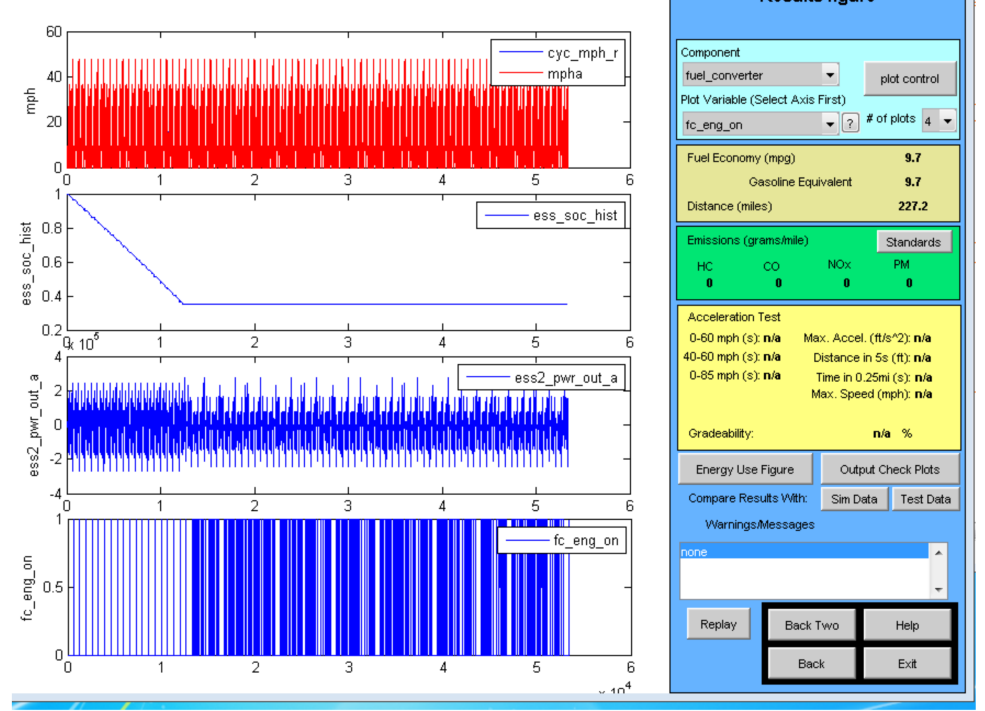

Figure 5. PHEVs using the $4.1 \mathrm{~V}$ supercapacitors on urban driving cycles.

\subsection{Fuel Cell Vehicles (FCV) Using Supercapacitors}

Fuel cell vehicles are hybrid-electric vehicles using a battery to assist the fuel cell during periods of high-power demand and to recovery energy during vehicle braking. As in HEVs, supercapacitors can replace the power battery. The supercapacitors are more efficient than the battery, especially during regenerative braking in large vehicles. Advisor simulations using fuel cells $[20,21]$ were run for some of the same vehicles as were evaluated under the HEVs category. The fuel cell efficiency used in the simulations was $60 \%$. The results of the simulations are shown in Table 9. In general, the vehicles using supercapacitors had slightly higher equivalent fuel economy than the corresponding vehicle 
using a battery. As found in [20,21], the effect of hybridization on fuel consumption using fuel cells is smaller than in vehicles using engines. Note from Table 9 that the advanced Aowei supercapacitors are also smaller and lighter than the lithium battery they can replace. The advantage of the supercapacitors in terms of increasing the fuel economy decreases for larger vehicles that require higher power from the fuel cell. However, in larger vehicles, the advantage in size of the supercapacitor compared to the battery is greater. To a good approximation, the hydrogen consumption is

$$
\mathrm{kgH} 2 / \mathrm{mi}=1 / \mathrm{mpgG} \text { equivalent }
$$

Advisor output graphics are shown in Figure 6 for several types of vehicles using fuel cells.

Table 9. Summary of the Advisor fuel cell simulation results and key inputs.

\begin{tabular}{|c|c|c|c|c|c|c|c|}
\hline & kg & L & Wh & EM kW & Mpg * FUDS & Mpg * Highway & Efficiency \% \\
\hline \multicolumn{8}{|l|}{ Mid-size car } \\
\hline $\begin{array}{l}\text { ICE gasoline } \\
\text { Lithium battery }\end{array}$ & 28 & 11.2 & 4508 & 160 & $\begin{array}{l}34.7 \\
107\end{array}$ & $\begin{array}{c}46 \\
95.9\end{array}$ & 91 \\
\hline EDLC Skeleton & 34 & 24.3 & 279 & 100 & 113.5 & 96.9 & 97 \\
\hline Aowei $3.8 \mathrm{~V}$ & 18 & 12.9 & 720 & & 108.3 & 95.7 & 94 \\
\hline $\begin{array}{l}\text { Aowei } 4.1 \mathrm{~V} \\
\text { small SUV }\end{array}$ & 12 & 8.6 & 780 & & 109.9 & 95 & $95(1 / 2 R)$ \\
\hline ICE gasoline & & & & & 35.3 & 44.7 & \\
\hline Lithium battery & 25 & 10 & 4025 & 160 & 85.2 & 77.3 & 87 \\
\hline EDLC Skeleton & 34 & 24 & 279 & & 95.3 & 77.9 & 97 \\
\hline Aowei $3.8 \mathrm{~V}$ & 13 & 9.3 & 520 & & 90.6 & 76.5 & 93 \\
\hline Aowei $4.1 \mathrm{~V}$ & 10 & 7.1 & 650 & & 92.5 & 77.3 & $95(1 / 2 R)$ \\
\hline \multicolumn{8}{|l|}{ Delivery van } \\
\hline ICE diesel & & & & & 12.8 & 12.7 & \\
\hline Lithium battery & 53 & 21.2 & 8533 & 200 & 27.9 & 22.5 & 86 \\
\hline EDLC Skeleton & 43 & 30.7 & 353 & & 29.4 & 22.6 & 94 \\
\hline Aowei $3.8 \mathrm{~V}$ & 35 & 25 & 1400 & & 28.5 & 22.6 & 991 \\
\hline Aowei 4.1 V & 25 & 17.9 & 1625 & & 28.7 & 22.6 & $94(1 / 2 R)$ \\
\hline \multicolumn{8}{|l|}{ Long haul truck } \\
\hline ICE Diesel & & & & & 4.0 & 6.9 & \\
\hline Lithium battery & 169 & 68 & 21,735 & 350 & 6.4 & 10.5 & 85 \\
\hline EDLC Skeleton & 135 & 96 & 935 & & 6.7 & 10.5 & 97 \\
\hline Aowei $3.8 \mathrm{~V}$ & 86 & 61 & 2960 & & 6.5 & 10.5 & 94 \\
\hline Aowei $4.1 \mathrm{~V}$ & 52 & 37 & 2860 & & 6.6 & 10.5 & 93 (1/2 R) \\
\hline
\end{tabular}

${ }^{*}$ Fuel cell efficiency $60 \%$.

As was the case with hybrid vehicles using engines, there has been very little published data on the use of supercapacitors in fuel cell vehicles in recent years. Both Honda and Hyundai used supercapacitors in their early development of fuel cell vehicles [22,23], but both switched to lithium batteries in their later developments. However, there have been many analyses performed on fuel cell systems that show supercapacitors will function well in fuel cell systems [24,25]. In addition, there have been many laboratory studies of supercapacitors with fuel cells that show that supercapacitors and fuel cells are very compatible [26,27]. Hence, with the large increase in the energy density, and the related expected large reduction in cost (USD/kWh), of supercapacitors, they should be seriously considered for fuel cell hybrid vehicle applications. 
Fuel cell midsize passenger car on the FUDS cycle using the $4.1 \mathrm{~V}$ supercapacitor
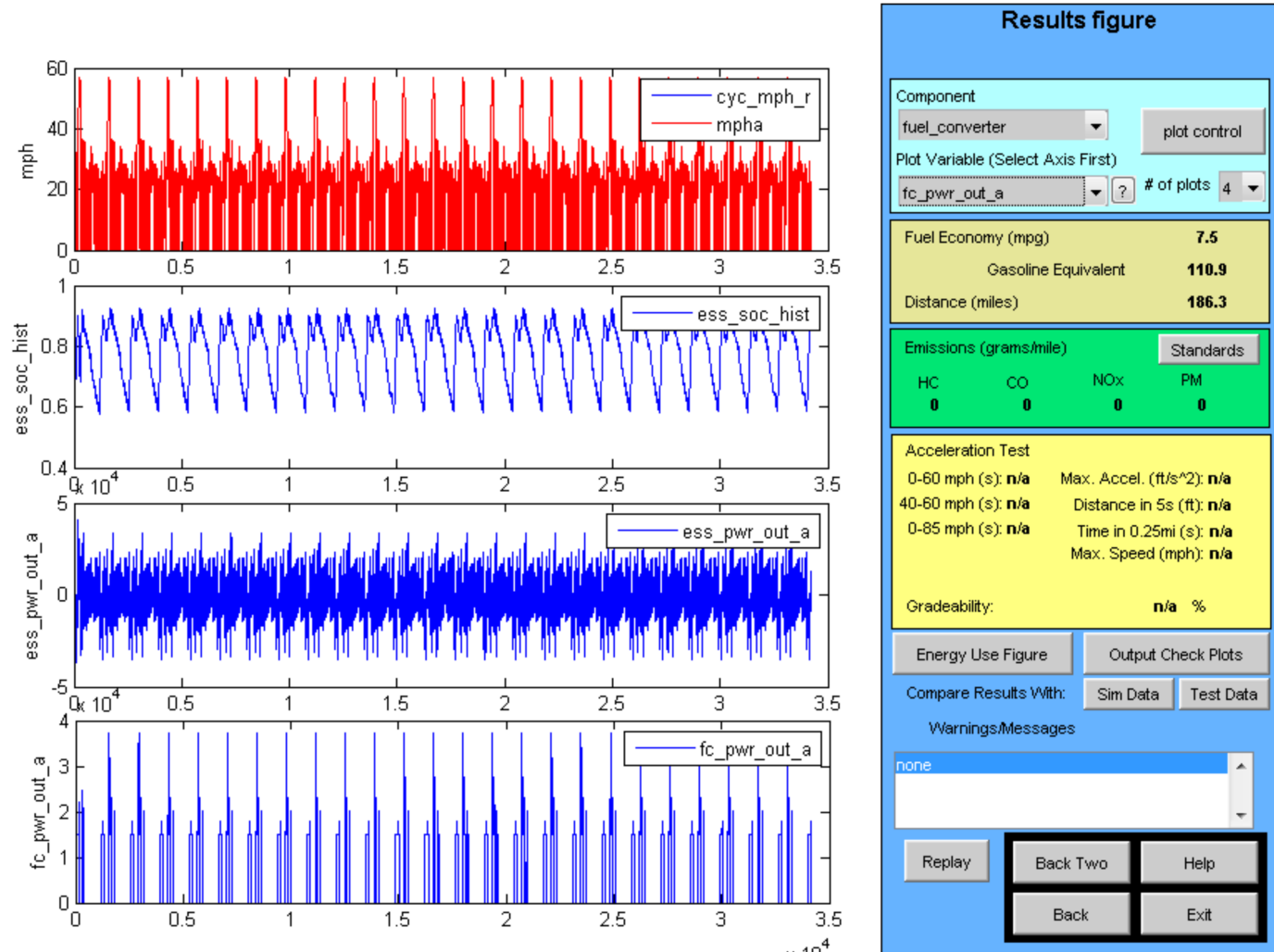

Fuel cell city delivery van on FUDS with $4.1 \mathrm{~V}$ supercapacitor
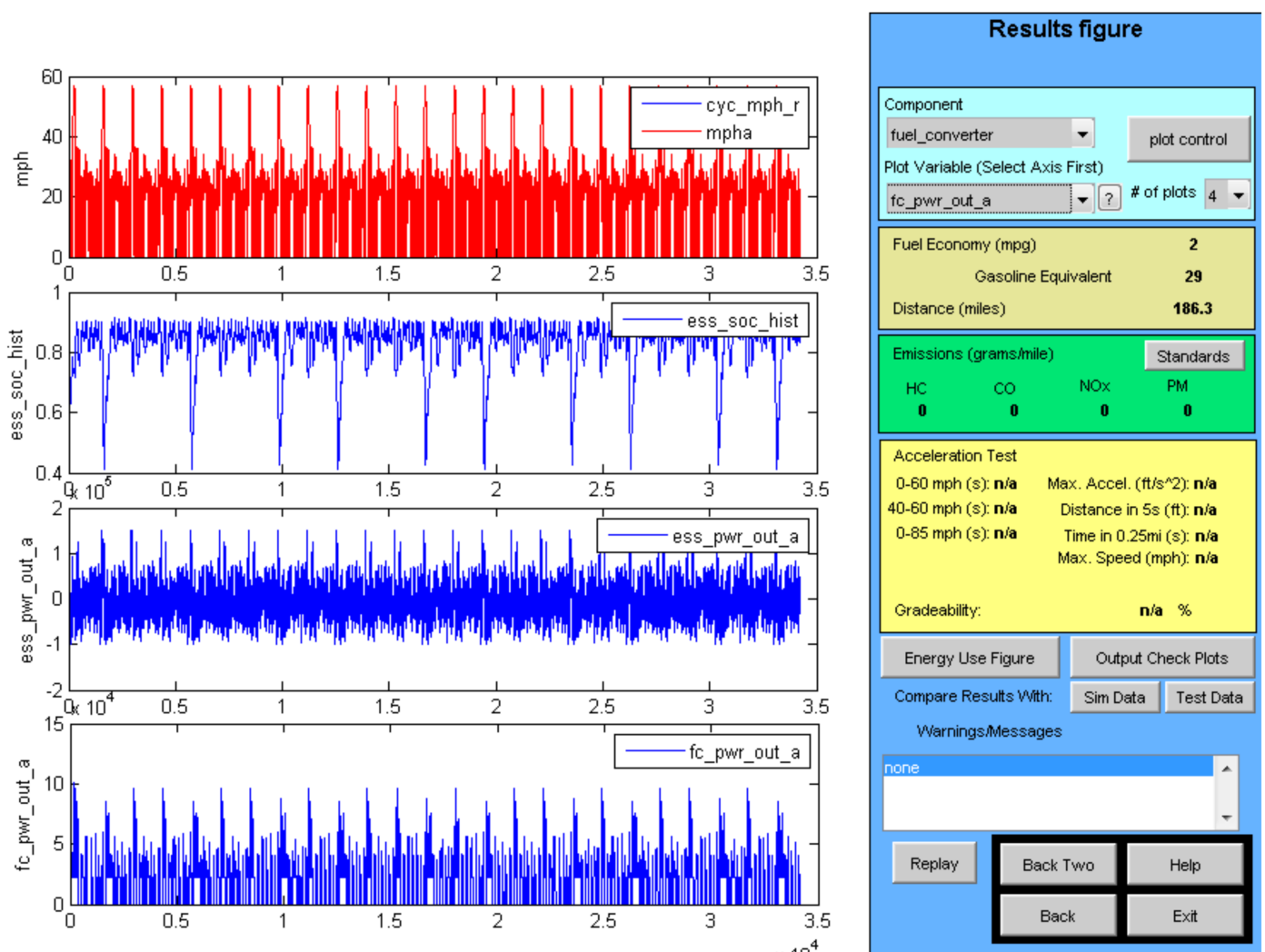

Figure 6. Fuel cell vehicles using the $4.1 \mathrm{~V}$ supercapacitors on urban driving cycles. 


\section{Summary and Conclusions}

This paper is concerned with the development and performance of high-energy density electrochemical supercapacitors (ECCs) and their application in HEVs, PHEVs, and HFCVs. Detailed test data are shown for the Skeleton Technology $5000 \mathrm{~F}$ carbon/carbon EDLC device and the Aowei $9000 \mathrm{~F}$ hybrid (4 V) supercapacitor (SC). The EDLC device had an energy density of $8.4 \mathrm{Wh} / \mathrm{kg}$, and the hybrid SC had an energy density between 30 and 65 , depending on its rated voltage and the power of the discharge. These energy densities are significantly higher than previous electrochemical capacitors tested. They indicate that progress is being made in increasing the energy density of commercial ECCs. Further progress is expected as the advanced electrode materials being studied in the laboratory, which have high specific capacitance $(\mathrm{F} / \mathrm{g})$, begin to be used in commercial products. It is important that the high-energy density capacitors have a high power capability, which will be the case if EDLC devices have an RC time constant less than $1 \mathrm{~s}$ and the hybrid devices have an RC time constant less than 3-5 s.

Vehicle applications of the advanced EECs were evaluated based on Advisor simulations on city and highway driving cycles. Simulations were made for six vehicle types ranging from compact passenger cars to Class 8 long haul trucks. The fuel economy was calculated for each vehicle type using a lithium battery, the EDLC Skeleton Technology capacitor and the two Aowei hybrid capacitors as energy storage in the powertrain. The energy storage units were sized such that their round-trip efficiencies on the simulated driving cycles were close to $90 \%$. For all vehicle types, the weight and volume of the capacitors decreased in the expected order; EDLC, hybrid 3.8 V, hybrid 4.1 V. The $4.1 \mathrm{~V}$ hybrid capacitor in all cases was lighter and smaller than the lithium battery. The fuel economies of the HEVs on the FUDS cycle were significantly higher (30-50\%) than that of the corresponding ICE vehicle, except for the long haul truck, for which the fuel economy improvement was $20 \%$. The effect of hybridizing on fuel economy on the highway cycles was small, at most $10 \%$, but it was much less in most cases. The effect on the highway fuel economy of the long haul truck was 4-6\%. In most cases, the fuel economy improvement was highest when using the $4.1 \mathrm{~V}$ hybrid capacitor. The estimated cost of the $4.1 \mathrm{~V}$ hybrid capacitor was USD 210/kWh. Hence, since the capacitor stores less energy than the battery by a factor of 5-6, its cost will be less than that of the battery.

Simulations were also run for fuel cell-powered vehicles using the same lithium battery and capacitors for energy storage to assist the fuel cell. The fuel consumption of the fuel cell vehicles is given in terms of equivalent gasoline consumption, which translates to $(1 / \mathrm{mi} / \mathrm{gal}) \mathrm{kgH} 2 / \mathrm{mi}$. For the fuel cell vehicles, the fuel economies using the three energy storage technologies varied only slightly. For all the fuel cell vehicles simulated, the $4.1 \mathrm{~V}$ hybrid capacitor was the lightest and smallest of the energy storage options, and produced the best fuel economy. As in the case of HEVs, the hybrid capacitors appeared to be the best option for energy storage in vehicle applications.

Author Contributions: Conceptualization, A.F.B. and J.Z.; methodology, A.F.B.; software, A.F.B. and J.Z.; validation, A.F.B.; data curation, A.F.B. and J.Z.; writing-original draft preparation, A.F.B.; writing-review and editing, A.F.B. and J.Z.; project administration, A.F.B. All authors have read and agreed to the published version of the manuscript.

Funding: This research received no external funding.

Institutional Review Board Statement: Not applicable.

Informed Consent Statement: Not applicable.

Data Availability Statement: Data is contained within the article.

Conflicts of Interest: The authors declare no conflict of interest. 


\section{References}

1. Burke, A.F.; Zhao, J.Y. Past, Present, and Future of Electrochemical Capacitors: Technology, Performance, and Applications. J. Energy Storage 2021, 35, 10230. [CrossRef]

2. Burke, A.F. Electrochemical Capacitors. In The Handbook of Batteries, 5th ed.; Wiley: Hoboken, NJ, USA, 2018.

3. Zhao, J.Y.; Burke, A.F. Electrochemical Capacitors: Performance Metrics and Evaluation by Testing. Adv. Energy Mater. 2020, 11, 31-55. [CrossRef]

4. Zhao, J.Y.; Burke, A.F. Electrochemical Capacitors: Materials, technologies, and performance. Energy Storage Mater. 2021, 36, 31-35. [CrossRef]

5. Zhong, C.; Deng, Y.; Hu, W.; Sun, D.; Han, X.; Qiao, J.; Zhang, J. Electrolytes for Electrochemical Supercapacitors; CRC Press: Boca Raton, FL, USA, 2016.

6. Yu, L.; Chen, G.Z. Ionic liquid-based electrolytes for supercapacitor and supercapattery. Front. Chem. 2019, 7, 272. [CrossRef] [PubMed]

7. Macfarlane, D.R.; Kar, M.; Pringle, J.M. Fundamentals of Ionic Liquids; Wiley-VCH: Weinheim, Germany, 2017.

8. Aowei Technology. Product Brochure; Aowei Technology: Shanghai, China, 2008.

9. Zhao, J.; Gao, Y.; Burke, A.F. Performance testing of supercapacitors: Important issues and uncertainties. J. Power Sources 2017, 363, 327-340. [CrossRef]

10. Burke, A.F. Chapter 12, Testing of electrochemical capacitors. In Supercapacitors: Materials, Systems, and Applications; Beguin, F., Frackowiak, E., Eds.; Wiley: Hoboken, NJ, USA, 2013.

11. Wipke, K.; Cuddy, M.; Bharathan, D.; Burch, S.; Johnson, V.; Markel, A.; Sprik, S. Advisor: A Second-Generation Advanced Vehicle Simulator for System Analysis; NREL/TP-540-25928; US Department of Energy: Washington, DC, USA, 1999.

12. Burke, A.; Zhao, H. Applications of Supercapacitors in Electric and Hybrid Vehicles; Report UCD-ITS-RR-15-09; Institute of Transportation Studies: Berkely, CA, USA, 2015.

13. Burke, A. Ultracapacitors in Hybrid and Plug-in Electric Vehicles. In Encyclopedia of Automotive Engineering; Crolla, D., Foster, D.E., Kobayashi, T., Vaughan, N., Eds.; John Wiley \& Sons Ltd.: Chichester, UK, 2014. [CrossRef]

14. Burke, A.F.; Zhao, H.; Van Gelder, E. Simulated Performance of Alternative Hybrid-Electric Powertrains in Vehicles on Various Driving Cycles. In Proceedings of the EVS-24, Stavanger, Norway, 13-16 May 2009.

15. Burke, A.F.; Zhao, H. Considerations in the use of supercapacitors in combination with batteries in vehicles. In Proceedings of the EVS-30, Stuttgart, Germany, 9-11 October 2017.

16. Burke, A.F.; Sinha, A.K. Energy Storage Considerations for 48 V Hybrid-Electric Powertrains; AABC: San Diego, CA, USA, 2019.

17. Pesaran, A.; Gonder, J.; Keyser, M. Ultracapacitor Applications and Evaluation for hybrid and electric vehicles. In Proceedings of the 7th Annual Advanced Capacitor World Summit, La Jolla, CA, USA, 31 March-2 April 2009.

18. Gonder, J. Evaluation of lower-energy energy storage systems for full-hybrid vehicles (HEVs). In Proceedings of the SAE 2013 Hybrid and Electric Vehicle Symposium, Anaheim, CA, USA, 20-21 February 2013.

19. Gonder, J.; Pesaran, A.; Lustbar, J.; Tataria, A. Hybrid vehicle comparison testing using ultracapacitors vs, battery storage. In Proceedings of the SAE 2010 Hybrid Vehicle Technology Symposium, San Diego, CA, USA, 11-12 February 2010.

20. Zhao, H.; Burke, A.F. Fuel cell Powered Vehicles using Supercapacitors: Device characteristics, control strategies, and simulation results. Fuel Cells 2010, 10, 879-896. [CrossRef]

21. Zhao, H.; Burke, A.F. Optimization of Fuel Cell Vehicle Operating Conditions for Fuel Cell Vehicles. J. Power Sources 2009, 186, 408-416. [CrossRef]

22. Song, M. Hyundai's 2nd Generation Hydrogen Fuel Cell Electric Bus Unveiled at the Seoul Motor Show. Available online: https: / / webcache.googleusercontent.com/search?q=cache:5g_QITaO0s8J:https:/ / www.hyundainews.com/assets / documents / original/19213-Hyundai\%25E2\%2580\%2599s2ndGenerationHydrogenFuelCellElectricBusUnveiledatSeoulMotorShow.doc+ $\& \mathrm{~cd}=1 \& \mathrm{kl}=\mathrm{zh}-\mathrm{CN} \& \mathrm{ct}=\mathrm{clnk} \& \mathrm{gl}=\mathrm{us}$ (accessed on 2 February 2022).

23. Xun, Q.; Lindberg, S.; Liu, Y. Design and Experiental Verification of a Passive/supercapacitor Configuration for a Light Vehicle. J. Energy Storage 2021, 33, 102110. [CrossRef]

24. Departure, C.; Macias, A.; Jacome, A.; Boulon, L.; Solano, J.; Trovão, J.P. Fuel cell/supercapacitor passive configuration sizing approach for vehicular applications. Int. J. Hydrog. Energy 2020, 45, 26501-26512. [CrossRef]

25. Thounthong, P.; Rael, S.; Davat, B. Control Strategies for Fuel Cell/Supercapacitor Hybrid Power Sources. J. Power Sources 2006, 158, 806-814. [CrossRef]

26. Wu, B.; Parkes, M.A.; Yufit, V.; De Benedetti, L.; Veismann, S.; Wirsching, C.; Vesper, F.; Martinez-Botas, R.F.; Marquis, A.J.; Offer, G.J.; et al. Design and Testing of a 9.5 KWe Proton Exchange Membrane-Supercapacitor Passive Hybrid System. Int. J. Hydrog. Energy 2014, 39, 7885-7896. [CrossRef]

27. Yeetserm, R.; Maiket, Y.; Kaewanee, W. The observation of supercapacitors effects on PEMFC-supercapacitor hybridization performance through voltage degradation and electrochemical processes. RSC Adv. 2020, 10, 13100-13111. [CrossRef] 